\title{
Farklı Yat Tiplerinin Ön Tasarım Aşamasında Makine Dairesi Parametrelerinin Belirlenmesi
}

\author{
Bülent Ibrahim TURAN \\ Muğla Sıtkı Koçman Üniversitesi, Muğla, Türkiye \\ bulentturan@mu.edu.tr, ORCID: 0000-0001-9690-6955
}

\section{ÖZET}

Yat tasarımı, gemi inşa mühendisliği ile endüstri ürünleri tasarımı ve iç mimarlık disiplinlerinin bir araya geldiği disiplinlerarası bir süreçtir. Yatların içinde bulundukları deniz ortamının dinamik ve zorlayıcı özelliği, denizde can ve mal güvenliğinin sağlanması açısından mühendislik disiplini, yat tasarım sürecindeki öncü disiplin olarak görülmektedir. Öte yandan estetik ve kişiselleştirme gibi kavramların öneminin günümüzde artmasıyla birlikte yat tasarım sürecinde tasarım ve iç mimarlık disiplinlerine duyulan ihtiyaç da giderek artmaktadır. Bir yatın gövdesinin özellikle ön tasarım aşamasında bölmelendirilmesi, yat tasarım sürecinin başlangıcında yer alan süreçlerden biri olmakla birlikte, ilerleyen tasarım süreçlerine yol gösterici niteliktedir. Bu sebeple, kısıtı bir alan olan tekne gövdesinin ne kadarlık bir kısmının teknenin sevk, idare ve güvenliği açısından kritik öneme sahip bölümü olan makine dairesine ayrılması gerektiğinin bilinmesi tasarım sürecindeki yerleşim ve iç mekân tasarım süreçlerinde yol gösterici olacaktır. Bu araştırmada farklı yat tiplerinin sahip oldukları makine dairesi alanları, makine dairesi başlangıç ve bitiş noktaları ile ilgili uygulanabilir değerlerin elde edilmesi hedeflenmiş, bu kapsamda yelkenli yat ve motoryat tiplerinde toplamda 72 adet yatın projeleri üzerinden veri toplanmıştır. Araştırma sonucunda, makine dairesinin uzunluğun teknenin gövde boyuna oranı ile teknenin gövde boyu üzerinden makine dairesi başlangıç ve bitiş noktalarının tekne tipine bağlı olarak elde edilmiştir. Sonuçlar, makine dairesinin tekne gövdesinde kapladığı bölümün yüzdesinin incelenen teknelerin tam boyu ile ters orantılı olarak logaritmik dağılım gösterdiğini ortaya koymaktadır. Bununla birlikte makine dairesinin tekne tam boyuna oranla tekne gövdesinde kapladığı bölge, Bodrum Guleti ve aynakıç tipi teknelerde \%11-\%18 aralığında hesaplanırken bu aralık incelenen motoryat tiplerinde \%14-\%21 aralığına yükselmektedir. Söz konusu değerler yat tasarımının ön tasarım sürecinde gerek mühendislik gerekse yat iç mekân bölmelendirme ve tasarım süreçlerine katkıda bulunur niteliktedir.

Anahtar kelimeler: Yat tasarımı, Gemi inşa mühendisliği, Tasarım süreci, Makine dairesi, Yat tipleri Makale geçmişi: Geliş 30/09/2021 - Kabul 11/12/2021

https://doi.org/10.54926/gdt.1002636 


\title{
Determination of Engine Room Parameters in Preliminary Design Process of Different Yacht Types
}

\author{
Bülent Ibrahim TURAN \\ Muğla Sıtkı Koçman Üniversitesi, Muğla, Türkiye \\ bulentturan@mu.edu.tr, ORCID: 0000-0001-9690-6955
}

\begin{abstract}
Yacht design is a process that includes different disciplines such as naval architecture, design and interior architecture. The dynamic and challenging marine environment that surrounds the yachts requires many engineering calculations to ensure the safety of life and property. On the other hand, increased importance of concepts of aesthetics and personalization, the need for design and interior architecture disciplines in the yacht design process increases. Partitioning the hull, during the preliminary design phase guides the progressive design processes in yacht design. For this reason, knowing how much of a limited area of the hull should be reserved for the engine room, which is a critical part of the boat's cruise and safety, will facilitate the design processes. In this research, the engine room areas of different boat types were examined, and 72 yachts were investigated. As a result, the ratio of the length of engine room to the hull length of the yachts, the starting and ending points of the engine room over the length of the hull of a yacht were obtained depending on the boat type. The results reveal that the investigated vessels show a logarithmic distribution inversely proportional to their full length. The results reveal that the percentage of the engine room occupied by the hull has a logarithmic distribution inversely proportional to the full length of the boats studied. Moreover, the area occupied by the engine room on the hull compared to the full length of the boat is calculated in the range of $11-18 \%$ in Bodrum Gulet and transom stern type sailing yachts, while this range increases to the range of $14-21 \%$ in the motor yacht types examined. These values will contribute to naval architecture, yacht interior partitioning and design processes in the preliminary design process of yacht design.
\end{abstract}

Keywords: Yacht design, Naval architecture, Design process, Engine room, Yacht types

Article history: Received 30/09/2021 - Accepted 11/12/2021 


\section{Giriş}

Geçmişte yaşanan deniz kazalarından çıkarılan dersler doğrultusunda hazırlanmış olan ve denizde can ve mal güvenliğini sağlama amacı taşıyan pek çok kural ve yönetmelik, yat tasarımında mühendislik sürecine kılavuzluk etmektedir. Gemi ve Su Araçlarının İnşa, Tadilat ve Bakım-Onarım Yönetmeliği (Türkiye Cumhuriyeti Ulaştırma ve Altyapı Bakanlığı, 2015) ve Yatların Yapımı ve Klaslamasına Illişkin Kurallar (Türk Loydu, 2019) yat mühendislik, tasarım ve inşa aşamalarında uygulanan kural ve yönetmeliklere örnek olarak verilebilir. Bununla birlikte, yatın kullanım amacına uygun ve verimli bir şekilde sevk ve idaresinin hedeflendiği hidrostatik ve hidrodinamik pek çok mühendislik hesabı da yat tasarım sürecinde etkin faktörlerdir. Bir teknenin gemi inşa mühendisi veya tekne tasarımcısı dışında farklı disiplinden gelen bir tasarımcı tarafından tasarlanması durumunda projenin bir gemi inşa mühendisi tarafından onaylanması gerekmektedir (Arslan, 2010).

Thomas (2015), yatlarda tasarım sürecinin, hız, ağırlık ve güçten oluşan altın üçgenin dengesi etrafında döndügünü belirtmektedir. Bununla birlikte (Büyükkeçeci ve Turan, 2018) güvenlik konusu da yat tasarım sürecinde belirleyici temel unsurlardan birisidir. Larsson ve Eliasson (2006), yat tasarım sürecinin nitel bir süreç değil, nicel bir süreç olduğunu ve çeşitli niceliklerin doğru hesaplanamaması durumunda teknenin istenenden yavaş, pahalı ve emniyetsiz olabileceğini ifade etmektedir. Tüm bu faktörler, yat tasarım sürecinin mühendislik disiplininin önderliğinde gerçekleşmesinin nedenini ortaya koymaktadır. Diğer deniz araçlarının tasarım sürecinde olduğu gibi yat tasarım sürecinde de verilen her bir kararın yatın fonksiyonellik, verimlilik, güvenlik, ekonomi ve konfor özellikleri üzerinde etkili olacağı unutulmamalıdır. Kullanıcıların taleplerinin toplanmasıyla başlayan tasarım süreci, bütçe ve süre kısıtlamasına uygun olarak optimum çözüm bulunana kadar yineleyen pek çok alt basamaktan meydana gelmektedir. Larsson ve Eliasson (2006) tarafından sunulan tasarım spirali (Şekil 1) yat tasarım sürecinin iteratif ve döngüsel yapısını vurgulamaktadır.

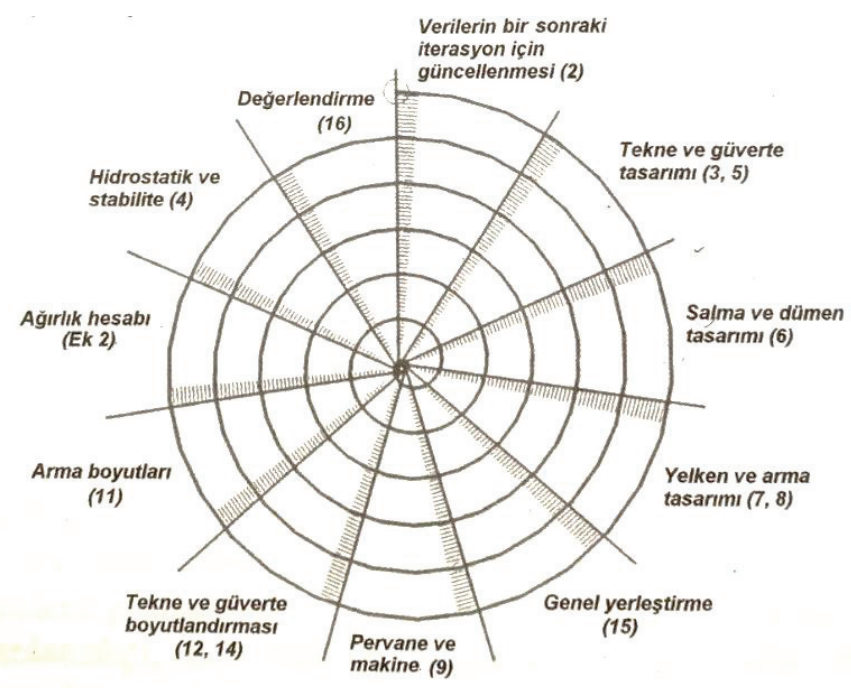

Şekil 1. Yat tasarım spirali (Larsson ve Eliasson, 2006)

Öte yandan, estetik ve kişiselleştirme kavramlarının bir tasarım ürünü olan yatlarda kendini göstermesiyle yat tasarım süreci yalnızca bir mühendislik disiplini olmaktan çıkmış, tasarım ve iç mimari gibi farklı disiplinleri ve barındıran disiplinler arası bir süreç haline gelmiştir. Kullanıılarının teknelerini özgün, farklı 
ve kullanıcı odaklı bir ürün haline getirme istekleri, yat tasarımında tasarım ve iç mimari süreçlerinin önemini artırmıştır. Örneğin renk, aydınlatma, doku seçimi ve tasarım kimliğinin yat iç mekânlara yansıtılması gibi süreçler, söz konusu disiplinlerin ön plana çıktığı çalışma alanlarından yalnızca birkaçıdır. Özellikle lüks yatlarda kişiselleştirme ve özgünlük açısından büyük bir öneme sahip olan tasarım, tekdüzeliğin önüne geçen bir kimlik olarak görülmektedir (Aydın ve Yılmaz Aydın, 2016).

Kullanııının talep ve istekleri doğrultusunda tekne tipinin ve ana boyutların belirlenmesinin ardından tekne gövdesinin bölmelendirilmesi süreci yer almaktadır. Göksel (2012), deniz araçlarında, mühendislik disiplini ile gemi ve yat tasarımı disiplinlerinin uzmanlık ve yetkisine dâhil olan bölümlerin, bir mimarlık ürününde olduğundan çok daha kesin sınırlarla ayrılmasına bağlı olarak deniz araçlarının iç mekânları için mimarlıkta kullanılan tefriş sözcüğü yerine bölmelendirme sözcüğünün kullanıldığını ifade etmektedir. Tekne gövdesinin bölmelendirilmesi aşamasında teknenin meyil ve trim durumu; dolayısıyla teknenin stabilite, manevra ve performans özellikleri göz önünde bulundurulmaktadır. Söz konusu mühendislik hesaplarının yanı sıra kabinlerde ses, titreşim ve düşey ivme hareketleri gibi konforu etkileyen faktörler de bölmelendirme sürecine şekil vermektedir. Şekil 2'de yelkenli yat tipi olan bir Bodrum Guleti'ne ait genel yerleşim planı ve profil çizimi görülmektedir.

Yat tasarım sürecinde iç mekân tasarımında zorlayıcı faktörlerden bir tanesi de tekne gövdesinin karasal mekânlara kıyasla oldukça zorlayıcı ve kıııtlı olan eğrisel forma sahip olmasıdır. Teknelerde kısıtlı olan iç hacimden dolayı, mimaride kullanılan ergonomi ölçülerinin bu alanlarda da uygulanması zor bir hal almaktadır (Koçoğlu ve Helvacıoğlu, 2016).

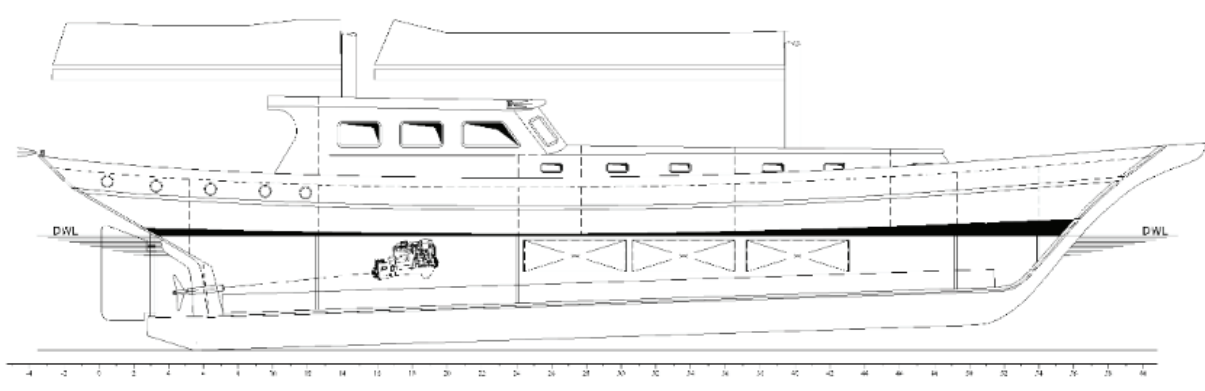

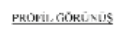
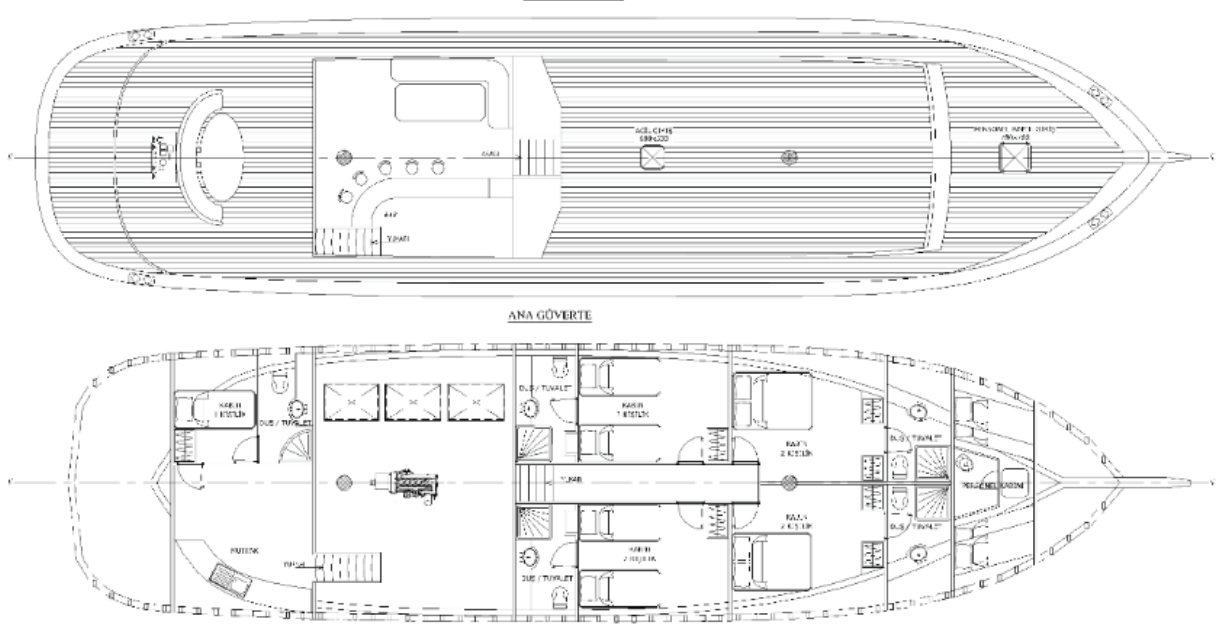

Şekil 2. Bir Bodrum Guleti'ne ait profil görünüş ve genel yerleşim planı çizimi 
Deniz araçlarının tasarım sürecinin başlangıcında motor, tesisat ve tanklar gibi sabit donanımlar için ihtiyaç duyulan alan gibi teknik bilgilerin tespit edilmesi önemli kritik rol oynamaktadır (Özer ve Tokol, 2021). Bir yatta bulunan teknik alanlar makine dairesi, zincirlik ve elektrik odası gibi alanlardır. Makine dairesi, bir deniz aracında ana makinelerin, yardımcı makinelerin, akü ve invertör gibi elektrik donanımının, yakıt tanklarının, çeşitli pompaların ve tüm bu donanımı destekleyen devre ve sistemlerin yer aldığı teknik alan olarak tanımlanabilir. Şekil 3'te bir yata ait makine dairesinin yerleşim çizimi görülmektedir.

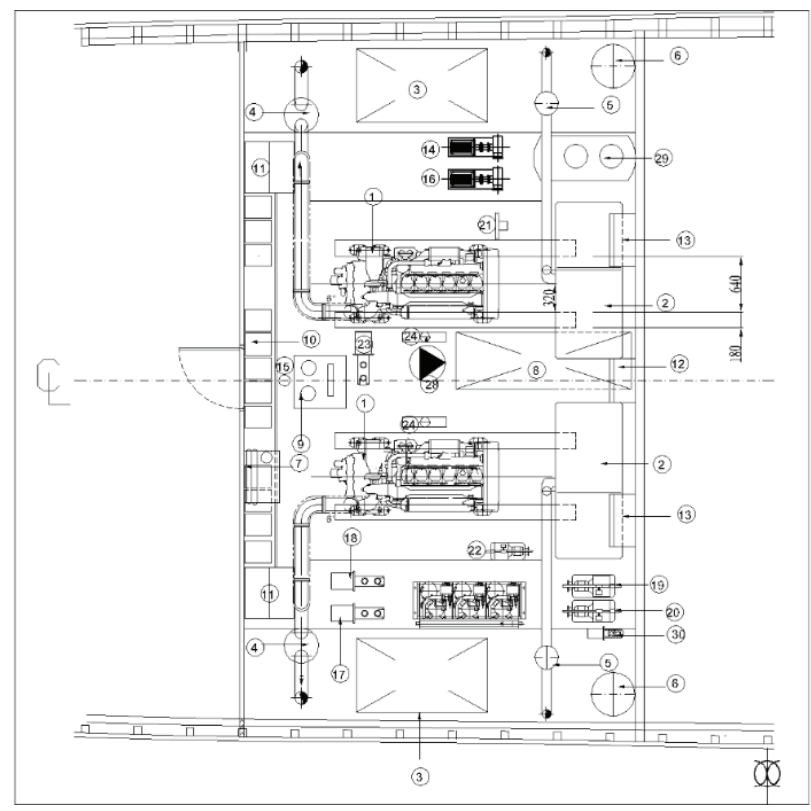

Şekil 3. Bir yata ait makine dairesi yerleşim planı

Şekil 4'te gösterilen ve Arslan (2010) tarafından sunulan tasarım spiralinde, kullanıcı istek \& amaçları ile başlayan tasarım süreci, piyasa araştırmasının ardından boyutlandırma ve oranlama süreci ile devam etmektedir. Turan (2021c) tarafından yapılan araştırmada da tekne tipi ile tekne ana boyutlarının belirlenmesi yat tasarım sürecinin ilk aşamaları arasında verilmektedir. Söz konusu başlangıç aşamalarında elde edilen az sayıdaki parametreyi kullanarak yat tasarım sürecinin ilerleyen aşamalarına kılavuzluk edilecek bağlantı ve grafiklerin elde edilmesi, yat tasarım sürecinin verimini artıracak bir unsurdur. Farklı amaca hizmet eden farklı tipteki gemilerin boyut, ağılık ve katsayı gruplarına ait değerlerin kullanılabilir bir grafikle gösterilerek armatörün veya istek sahibinin talepleri ile uyuşan yaklaşık değerlerin elde edilmesi, malzeme ve işçilik gibi konular hakkında ön bilgi sağlamak açısından oldukça faydalı görülmektedir (Kafalı, 1988).

Bu çalışma yat tasarım spiralinin ilerleyen basamak veya döngülerinde elde edilen farklı parametrelerin değil, tasarım sürecinin başlangıç noktasında elde edilen yat tipi, yatın tam boyu ve eninin kullanılarak makine dairesi ile ilgili sonuçlara ulaşılması amaçlanmıştır. Bu bağlamda araştırmada yat tasarım sürecinin başlangıç evresinde yatın yalnızca tipi, ana boyu ve genişliğinin kullanılarak sahip olacağı makine dairesinin başlangıç-bitiş noktaları ile tekne gövdesinde kapladığı bölümün tekne tam boyuna oranının elde edilmesini hedeflenmiştir. 


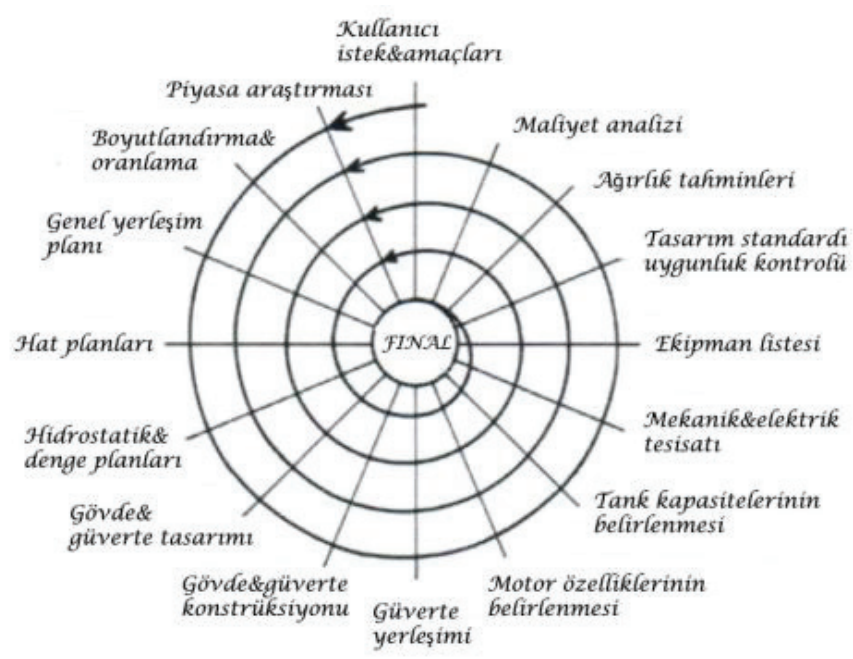

Şekil 4. Arslan (2010) tarafından sunulan tasarım spirali

\section{Yat tipleri}

Yatlar, yelkenli yatlar ve motoryatlar olarak iki ana sınıfa ayrılmakla birlikte, boyutları veya yapım malzemelerine göre de sınıflandırılabilmektedir (Tokol, 2020). Yelkenli yatlar ve motoryatlar da kendi içinde çeşitli alt sınıflara sahiptir. Tekne tipinin ve alt tipinin belirlenmesi, makine dairesinin özelliklerinin saptanmasında büyük öneme sahiptir. Yelkenli bir yatta makine dairesi için ayrılan alan ile aynı boya sahip, yüksek sürat beklentisinin ön planda olduğu bir motoryatta makine dairesi için ihtiyaç duyulan alan birbirinden farklıdır. Yat iç mekân tasarımında makine dairesi ile ilgili parametrelerin incelenerek ortalama değerlerin elde edilmesi için öncelikle yatlar, tiplerine göre gruplara ayrılmıştır.

\subsection{Yelkenli Yatlar}

Yelkenli yatlar gövde sayısına, arma tipine, yapım malzemesine veya gövde formuna göre çeşitli tiplere sahiptir. Gövde sayısına göre tek gövdeli, katamaran veya trimaran, arma tipine göre uskuna, keç, kotra, yavl, slup vb, yapım malzemesine göre ahşap, çelik, alüminyum veya kompozit, gövde formuna göre ise gulet, aynakıç, tırhandil gibi tipler, ülkemizde yaygın olarak karşılaşılan yelkenli yat tipleridir. Yelkenli teknelerin sınıflandırılmasında, teknelerin kullanıldığı bölgenin coğrafi ve kültürel etkilerine bağlı olarak tekne formları da değişiklik göstermektedir. Örneğin, Hollanda'da kullanılan bir yelkenli tekne formu ile Ege Denizi'nde kullanılan bir teknenin formu oldukça belirgin farklılıklar taşımaktadır. Bununla birlikte ülkemizin kıyılarında üretilen ve Türkiye'ye özgü pek çok yelkenli tekne tipi bulunmaktadır. Karadeniz Çektirmeleri, Karadeniz Guletleri, Piyade, Tırhandil, Bodrum Guleti, Aynakıç tipi tekneler, ülkemize özgü yelkenli tekneler arasında yer almaktadır (Köyağasıoğlu, 2014). Bu yelkenli tekne tiplerinden özellikle Bodrum Guletleri, Aynakıçlar ve tırhandil tipi tekneler deniz turizminin de etkisiyle yat olarak yaygın bir şekilde kullanılmaktadır. Bu tekneler arasında özellikle guletler, bölgedeki gezi teknelerinin çoğunluğunu oluşturmaktadır (Kükner, 2009).

Tarihte askeri, ticari yük taşımacılığı, süngercilik, balıkçılık farklı amaçlarda kullanılmış olan guletler, günümüzde turizm ve özellikle de Mavi Yolculuk sektörlerinde hizmet vermektedir (Kükner vd., 2009; Kükner ve Kınacı, 2009; Özen, 2017; Paker ve Özgeçmez, 2014; Turan ve Akman, 2021). Guletlerin Mavi 
Yolculuk'ta kullanılmaya başlanmasıyla birlikte, ticari kullanıma uygun kaygıların yerini alan estetik kaygısı, bu teknelerin Bodrum Guleti olarak adlandırılan günümüz formuna kavuşmasında büyük rol oynamıştır (Büyükkeçeci ve Turan, 2018). Bodrum Guletleri'nin özellikle baş kısımları, farklı bir kullanım amacı olan balıkçılıkta kullanılan guletlerinkinden farklı bir forma sahiptir (Turan, 2021a).Kendine has estetik çizgilere sahip olan Bodrum Guletleri, Mavi Yolculuk'un da etkisiyle simgesel ve tüm dünyada tanınan tekne formlarından biri haline gelmiştir (Turan ve Özcan, 2018). Eliptik kıç formu, şarap kadehi şeklinde orta kesiti ve iç bükey baş formu, Bodrum Guleti'nin karakteristik özellikleri olarak görülmektedir (Turan ve Akman, 2021). Bodrum Guletleri'nde, yolcu kabinlerinin çeşitliliği, havalandırma, aydınlatma ve dekor unsurlarının seçimi gibi pek çok donanım, kullanıcı tercihleri doğrultusunda şekillenmektedir (Turan, 2021). Şekil 5 'te bir Bodrum Guleti görülmektedir.

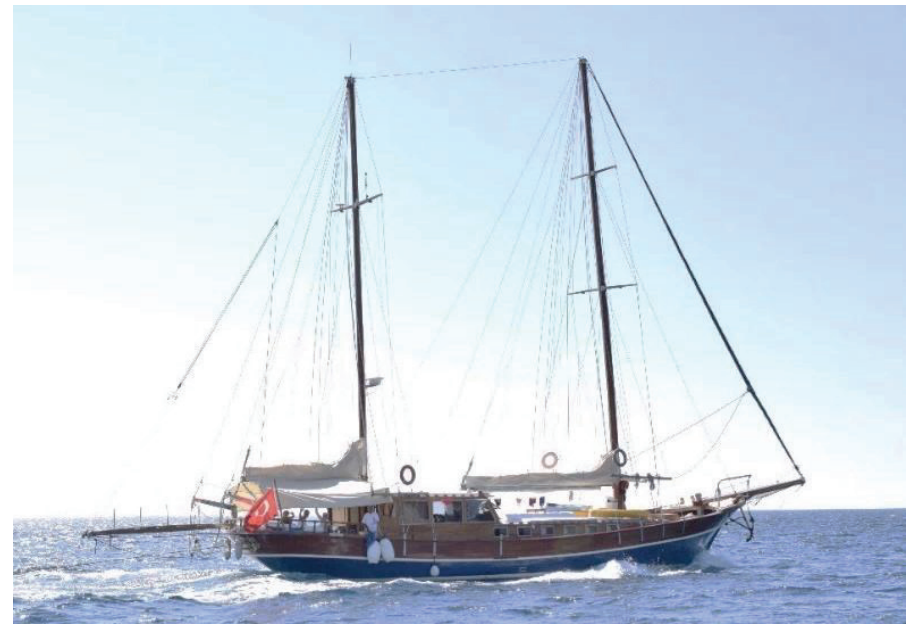

Şekil 5. Bodrum Guleti

Ülkemize özgü bir diğer yat tipi ise Bodrum Guletleri'nin kıç formunun değiştirilmesi ile ortaya çıkmış olan Aynakıç tipi teknelerdir. Aynakıç tipi tekneler, Mavi Yolculuk'ta kullanılan Bodrum Guletleri'nin alt güvertelerinde daha fazla alana ihtiyaç duyulmasının ardından ortaya çıkmıştır (Turan ve Akman, 2021). Aynakıç tipi teknelerin formu Bodrum Guleti'ne benzemekle beraber bu tekne tipinde, Bodrum Guletleri'nde yuvarlak forma sahip olan kıç formu ayna kıç formunda, yani çapraz bir kiriş şeklindedir (Kükner, 2009). Kıç formunun bu şekilde değiştirilmesi ile elde edilen ilave hacim kabin sayısının artmasında ve teknenin baş tarafında yer alan kabin ve mürettebat alanlarının rahatlatılmasında büyük rol oynamaktadır. Şekil 6'da Aynakıç tipi bir tekne görülmektedir. Turan ve Akman (2021) tarafından yapılan çalışmada Aynakıç tipi tekneler ile Bodrum Guletleri direnç açısından kıyaslanmış ve 10 knot seyir hızı için $28 \mathrm{~m}$ tam boyun üzerindeki teknelerde Aynakıç tipi teknelerin avantajlı hale geldiği sonucuna ulaşıımıştır.

\subsection{Motoryatlar}

Motoryatların form ve çeşitliliği yelkenli yatlara göre farklılık göstermektedir. Geleneksel bir forma sahip olmayan, dolayısıyla da gövde form açısından tasarımda çeşitlilğe açık olan motoryatlarda ortak bir formdan söz etmek oldukça zordur (Büyükkeçeci ve Turan, 2018). Her ne kadar gövdenin su altında kalan formu için deplasman, yarı-deplasman veya kayıcı form ayrımını yapmak mümkün olsa da bu ayrım teknelerin suyun üzerinde kalan kısımlarını tanımlamak için yeterli değildir. Bu noktada ise çeşitliliği 
oldukça fazla olan bir terminoloji devreye girmektedir. Lobster, trawler, open, sport, weekend, flybridge veya hard-top ve benzeri yat tipleri, yatların su üzerinde kalan kısımlarının tamamını veya bir kısmını baz alarak belirlenmiş motoryat tipleri arasında yer almaktadır. Bununla birlikte motoryatlar sahip olduğu tam boy üzerinden de süperyat ve megayat olarak sınıflandırılabilmektedir. Ancak bu sınıflandırma daha çok 25-30 m üzerinde tam boya sahip motoryatlar için kullanılmaktadır.

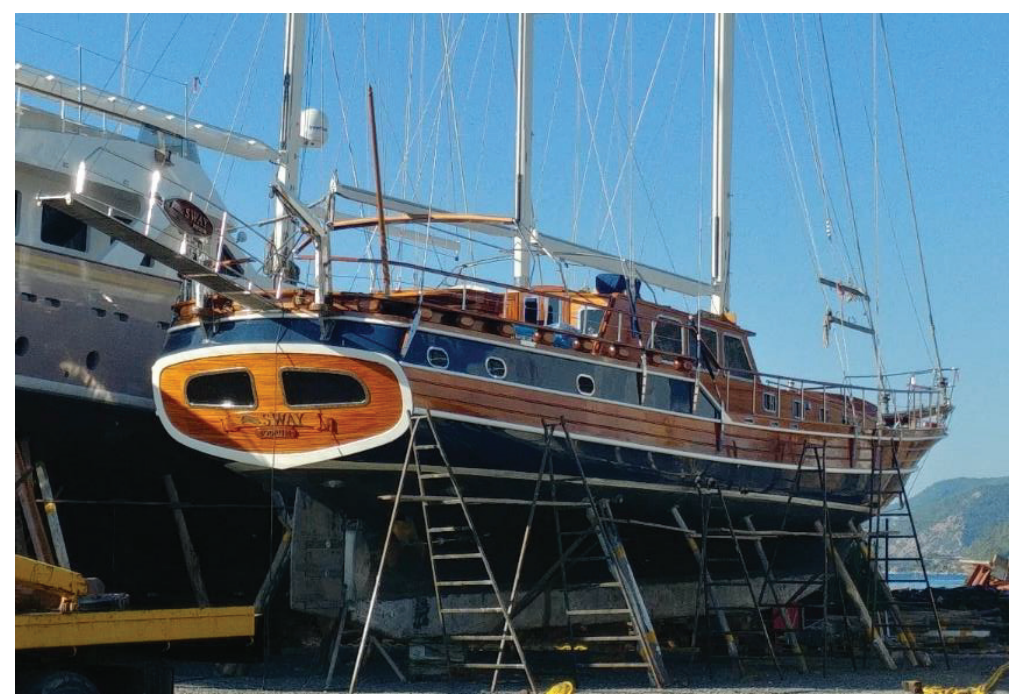

Şekil 6. Aynakıç tipi yelkenli yat

Araştırma kapsamında, karakteristik gövde formlarına sahip olan motoryatların seçilmesi hedeflenmiş, bu amaçla genellikle yarı deplasman gövde formuna sahip olan trawler tipi tekneler ile kayıcı gövde formuna sahip olan ve open, sport veya flybridge olarak adlandırılan motoryat tipleri seçilmiştir.

Trawler tipi motoryatlar, genellikle ana güvertelerinde bulunan kademe farkı sayesinde Lobster tipi teknelere kıyasla daha fazla iç hacim sunan, çoğunlukla bir alt, bir ana ve bir üst güverteye sahip olan motoryat tipleridir. Hızın çok fazla ön planda olmadığı bu tekne tipleri genellikle deplasman veya yarıdeplasman tipinde forma sahiptir. Şekil 7'de trawler tipi bir motoryat görülmektedir.

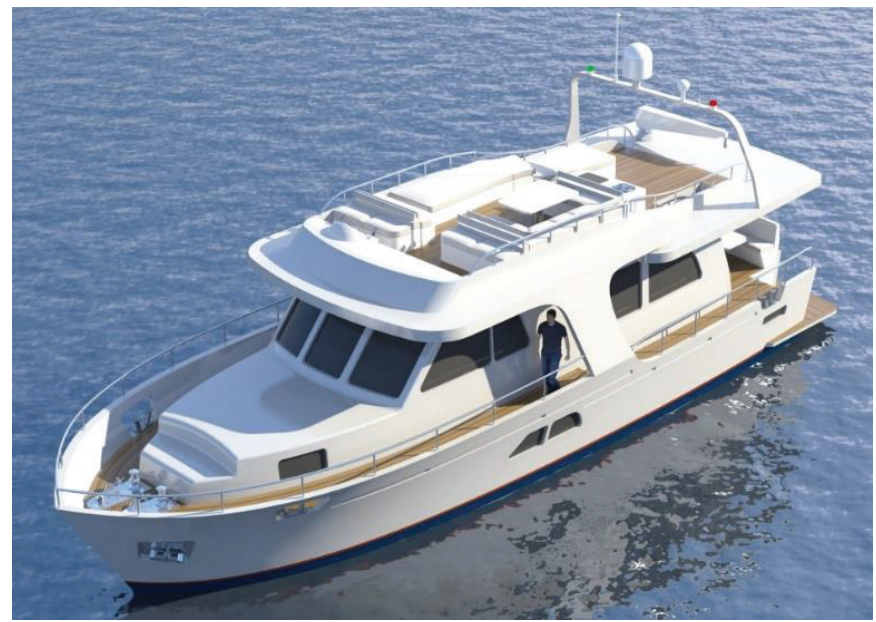

Şekil 7. Trawler tipi bir motoryat 
Motoryat tiplerinin nitelendirilmesi aşamasında en fazla karışıklık yaşanan tip ise kayıcı gövde formuna, modern hatlara ve 2 veya daha fazla güverteye sahip olan motoryatlardır. Bu motoryatlar open, sport, flybridge gibi farklı isimlerle tanımlanmaktadır. Şekil 8'de (Boat International Türkiye, 2021) flybridge olarak nitelendirilen bir motoryat görülmektedir.

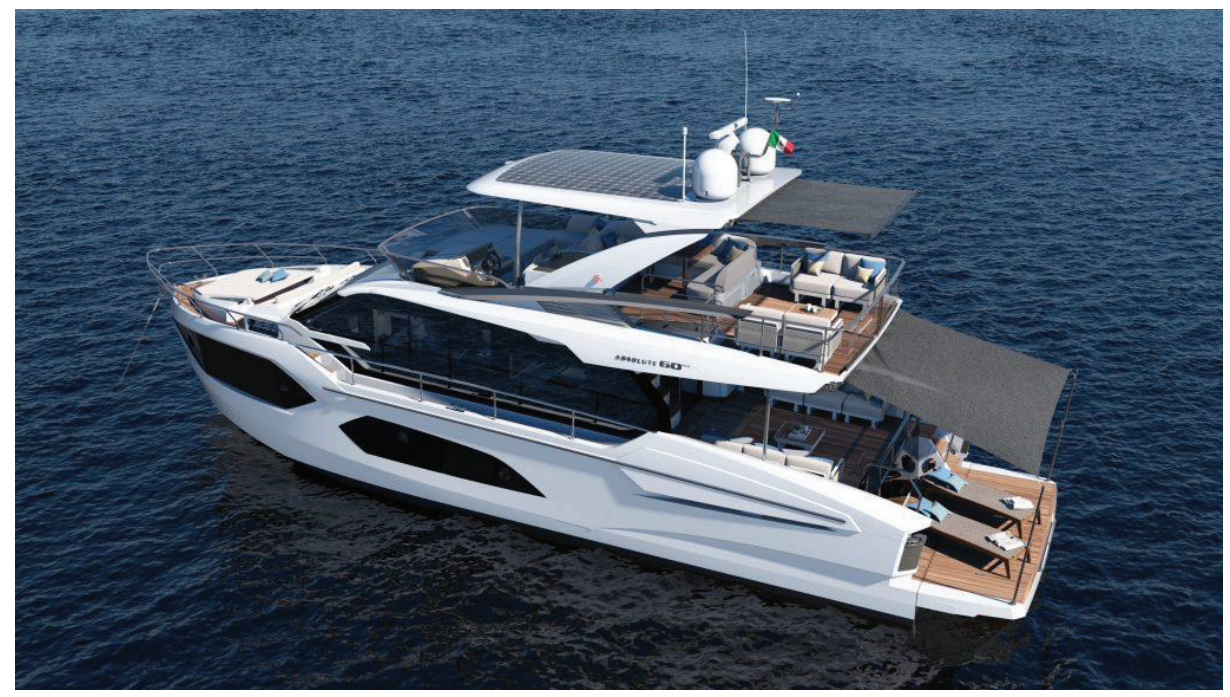

Şekil 8. Flybridge tipinde bir motoryat (Boat International Türkiye, 2021)

Trawler tipi motoryatlar ile flybridge, sport veya open olarak adlandırılan motoryatlar hız ve gövde formu üzerinden ayrışmaktadır. Trawler tipi teknelerde genellikle hız ön planda değilken flybridge, sport veya open tipi motoryatlarda hız ve performans ön plandadır. Bu sebeple söz konusu iki motoryat tipinde kullanılan makine ve yardımcı makinelerin arasındaki farklılık, makine dairesi alanlarına da yansımaktadır.

\section{Yöntem}

Araştırmada öncelikle literatür çalışması yapılmış, sonrasında ise farklı tipteki yatlara ait genel yerleşim planları incelenerek makine dairesi ile ilgili oran ve değerler elde edilmiştir. Yapılan araştırma, ayrıca Bodrum, İçmeler Tersaneler Bölgesi'nde ve Ören Çekek Bölgesi'nde gerçekleştirilen yerinde gözlem sırasında alınan görsellerle desteklenmiştir. İncelenen yatlar öncelikle yelkenli yatlar ve motoryatlar olarak iki ana gruba ayrılmış sonrasında her bir grup, alt kategorilere ayrımıştır. Toplamda 72 adet yatın projeleri incelenerek makine dairesinin konumu ve kapladığı alan ile ilgili bilgilere ulaşılmıştır. İncelenen yatların $30^{\prime}$ u yelkenli, $42^{\prime}$ si ise motoryat tiplerine aittir. Incelenen yelkenli yatların tamamı ahşap malzemeden imal edilmiş olup, incelenen motoryatların ise 7'si ahşap malzemeden, 19'u kompozit malzemeden ve 15'i de çelik ile alüminyum malzemeden imal edilmiştir.

Araştırma kapsamında yelkenli yat tipleri arasında, Türkiye’ye özgü yat tipleri olarak ön plana çıkan ve kişiye özel tasarım imkânları ile kullanııılara sayısız alternatif sunan Bodrum Guleti ve Aynakıç tipi yelkenli yatlar incelenmiştir. Tırhandil tipi yelkenli yatlar, karakteristik boy/en oranına bağlı olarak genellikle 20 metrenin üzerinde üretilmemekte ve bu yatların çoğunda makine dairesi baş ve kıç perdeyle belirlenmiş alanlar olarak değil, yalnızca baş perdeye sahip ve teknenin kıçına kadar uzanan alanlar olarak karşımıza çıkmaktadır. Motoryat tipleri arasında ise trawler ve open/sport veya flybridge olarak adlandırılan 
motoryat tipleri ele alınmıştır. Özellikle motoryatlarda yer alan kıç platformun uzunluğu tasarım tercihleri doğrultusunda değişiklik göstermekte ve teknenin tam boyuna dâhil edilmektedir. Öte yandan, platformun tekne gövdesinden bir çıkıntı olarak uzatıldığı durumlarda (Bkz. Şekil 7), platform boyu teknenin gövde formu ile ilgili hesaplamalara dahil edilmemektedir. Bu sebeple araştırmada makine dairesi ile ilgili oranların saptanmasında teknelerin tam boyu üzerinden değil, gövde boyu üzerinden değerlendirme yapılmıştır. İncelenen tekne tiplerinin sayıları aşağıda listelenmiştir.

- Yelkenli Yatlar: 15 adet Bodrum Guleti, 15 adet Aynakıç

- Motoryatlar: 10 adet trawler, 32 adet open/sport/flybridge

Araştırmada, yat tasarım sürecinde kullanılabilmek üzere, incelenen yatların genel yerleşim planlarından makine dairesi ölçüleri alınmış, bu değerler teknelerin gövde boyuna oranlanarak boyutsuz oranlar elde edilmiştir. Makine dairesinin tekne gövdesinde kapladığı bölgenin yüzdesi ile teknelerin tam boyu arasındaki ilişkininin saptanabilmesi için doğrusal, üstel ve logaritmik dağılım grafikleri çizilmiş, elde edilen grafiklerde eğilim çizgileri karşılaştııılmıştır. Yapılan karşılaştırmalar neticesinde, söz konusu iki parametre arasında logaritmik dağılımın diğer dağılımlara kıyasla daha verimli sonuçlar verdiği görülmüştür.

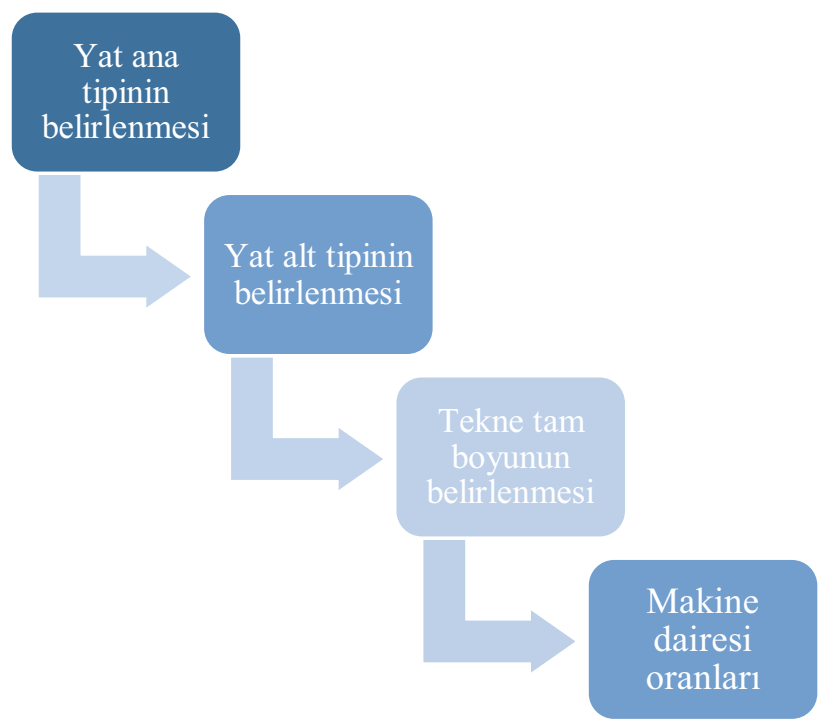

Şekil 9. Yat tasarım sürecinde makine dairesi oranlarını elde etme

Elde edilen grafik ve tablolar, yat tasarım sürecinde kılavuz olarak kullanıma uygun parametreleri sağlamaktadır. Şekil 9, araştırmada elde edilen veriler üzerinden yat tasarım sürecinde makine dairesi ile ilgili oranların belirlenme akışını göstermektedir.

\section{Bulgular}

Incelenen yatların her birisine tiplerine göre harf ve sayıdan oluşan bir kod verilmiştir. Aynakıç tipi tekneler A; Bodrum Guletleri G; trawler tipi motoryatlar T ve open/sport/flybridge tipi motoryatlar ise $\mathrm{F}$ harfleri ile kodlanmıştır. 


\subsection{Yelkenli Yatlar}

İncelenen 30 adet yelkenli yata ait değerler Tablo 1'de görülmektedir. Toplanan değerlerin teknelerin tam boyuna bölünmesiyle elde edilen oran tablosu Tablo 2'de görülmektedir.

Tablo 1. Incelenen yelkenli yatlara ait değerler

\begin{tabular}{|c|c|c|c|c|c|c|c|c|c|c|}
\hline $\begin{array}{c}\text { Tekne } \\
\text { No }\end{array}$ & $\begin{array}{c}\text { Tam Boy } \\
\text { (m) }\end{array}$ & $\begin{array}{c}\text { Gövde } \\
\text { Boyu (m) }\end{array}$ & $\begin{array}{c}\text { Su Hattı } \\
\text { Boyu } \\
\text { (m) }\end{array}$ & $\begin{array}{c}\text { Genişlik } \\
\text { (m) }\end{array}$ & $\begin{array}{l}\text { Motor } \\
\text { Adedi }\end{array}$ & $\begin{array}{c}\text { Makine } \\
\text { Dairesi } \\
\text { Boyu (m) }\end{array}$ & $\begin{array}{c}\text { Makine } \\
\text { Dairesi } \\
\text { Ortalama } \\
\text { Genişliği } \\
\text { (m) }\end{array}$ & $\begin{array}{c}\text { Mak. } \\
\text { Dairesi } \\
\text { Alanı }\left(\mathrm{m}^{2}\right)\end{array}$ & $\begin{array}{l}\text { Mak. } \\
\text { Dairesi Kıç } \\
\quad(\mathrm{m})\end{array}$ & $\begin{array}{c}\text { Mak. } \\
\text { Dairesi } \\
\text { Baş (m) }\end{array}$ \\
\hline A.1 & 20.30 & 20.30 & 16.80 & 5.60 & 2 & 3.76 & 5.15 & 19.36 & 4.85 & 8.61 \\
\hline A. 2 & 22.00 & 22.00 & 18.00 & 6.20 & 1 & 3.80 & 6.00 & 22.80 & 5.90 & 9.70 \\
\hline A.3 & 23.00 & 23.00 & 18.80 & 6.32 & 1 & 3.95 & 5.75 & 22.71 & 5.75 & 9.70 \\
\hline A.4 & 23.26 & 23.26 & 18.65 & 6.34 & 1 & 4.00 & 5.86 & 23.44 & 5.60 & 9.60 \\
\hline A.5 & 23.41 & 23.41 & 20.50 & 6.60 & 2 & 4.14 & 6.11 & 25.30 & 6.48 & 10.62 \\
\hline A. 6 & 23.90 & 23.90 & 20.14 & 6.42 & 1 & 3.70 & 5.80 & 21.46 & 6.32 & 10.02 \\
\hline A.7 & 24.90 & 24.90 & 21.57 & 5.60 & 1 & 3.88 & 6.10 & 23.67 & 6.77 & 10.65 \\
\hline A. 8 & 25.00 & 25.00 & 21.80 & 6.30 & 1 & 3.92 & 5.80 & 22.74 & 6.25 & 10.17 \\
\hline A.9 & 25.10 & 25.10 & 22.00 & 6.73 & 1 & 3.85 & 6.34 & 24.41 & 6.79 & 10.64 \\
\hline A.10 & 28.70 & 28.70 & 24.85 & 7.55 & 2 & 4.30 & 6.64 & 28.55 & 8.28 & 12.58 \\
\hline A.11 & 32.50 & 32.50 & 27.50 & 7.65 & 2 & 4.25 & 7.20 & 30.60 & 9.00 & 13.25 \\
\hline A.12 & 35.00 & 35.00 & 30.18 & 7.63 & 2 & 4.40 & 7.35 & 32.34 & 9.84 & 14.24 \\
\hline A.13 & 37.78 & 37.78 & 32.00 & 8.14 & 2 & 4.50 & 7.83 & 35.24 & 10.74 & 15.24 \\
\hline A.14 & 38.59 & 38.59 & 33.84 & 8.82 & 2 & 4.80 & 8.15 & 39.12 & 10.97 & 15.77 \\
\hline A.15 & 42.83 & 42.83 & 38.00 & 9.00 & 2 & 5.00 & 8.35 & 41.75 & 11.95 & 16.95 \\
\hline G.1 & 21.80 & 21.80 & 17.15 & 6.09 & 2 & 3.90 & 5.70 & 22.23 & 5.20 & 9.10 \\
\hline G.2 & 23.80 & 23.80 & 18.57 & 6.45 & 2 & 3.95 & 6.30 & 24.89 & 5.40 & 9.35 \\
\hline G.3 & 23.90 & 23.90 & 18.55 & 6.50 & 2 & 3.85 & 6.15 & 23.68 & 5.60 & 9.45 \\
\hline G.4 & 23.95 & 23.95 & 18.50 & 6.70 & 2 & 4.00 & 6.37 & 25.48 & 5.83 & 9.83 \\
\hline G.5 & 25.60 & 25.60 & 20.30 & 6.30 & 1 & 4.10 & 5.91 & 24.23 & 5.70 & 9.80 \\
\hline G.6 & 26.65 & 26.65 & 21.30 & 6.85 & 1 & 4.10 & 6.10 & 25.01 & 5.90 & 10.00 \\
\hline G.7 & 27.60 & 27.60 & 22.70 & 6.80 & 1 & 4.08 & 6.40 & 26.11 & 5.60 & 9.68 \\
\hline G.8 & 28.00 & 28.00 & 23.40 & 7.00 & 2 & 4.25 & 6.45 & 27.41 & 5.68 & 9.93 \\
\hline G.9 & 28.20 & 28.20 & 23.14 & 6.95 & 1 & 4.30 & 6.20 & 26.66 & 6.50 & 10.80 \\
\hline G.10 & 28.40 & 28.40 & 23.60 & 7.14 & 2 & 4.45 & 6.55 & 29.15 & 5.74 & 10.19 \\
\hline G.11 & 29.50 & 29.50 & 23.20 & 7.00 & 2 & 4.30 & 6.50 & 27.95 & 6.32 & 10.62 \\
\hline G.12 & 32.00 & 32.00 & 25.70 & 7.20 & 2 & 4.45 & 6.85 & 30.48 & 7.95 & 12.40 \\
\hline G.13 & 33.12 & 33.12 & 26.03 & 7.63 & 2 & 4.35 & 7.45 & 32.41 & 8.10 & 12.45 \\
\hline G.14 & 35.64 & 35.64 & 27.55 & 8.10 & 2 & 4.30 & 7.50 & 32.25 & 8.95 & 13.25 \\
\hline G.15 & 35.85 & 35.85 & 28.84 & 8.30 & 2 & 4.50 & 8.15 & 36.68 & 8.50 & 13.00 \\
\hline
\end{tabular}

Elde edilen verilere göre, Aynakıç ve Bodrum Guleti tipi yelkenli teknelerde makine dairesinin teknenin kıç uç noktasına referansla bulunduğu konumu, tekne boyuna göre çok fazla değişiklik göstermemekte, ancak makine dairesinin baş kısmının konumunun tekne tam boyuna oranının tekne boyuna göre değişiklik göstermektedir. İncelenen yelkenli yatlardaki makine dairesi boyunun tekne tam boyuna oranının yüzde şeklinde dağılımı Şekil 10'da yer almaktadır. Elde edilen sonuçlar hem Aynakıç tipi yelkenli teknelerde hem de Bodrum Guletleri'nde makine dairesi toplam uzunluğunun tekne tam boyuna oranı ile tekne tam boyu arasında ters orantı olduğunu ve söz konusu iki parametre arasında logaritmik dağılım bulunduğunu göstermektedir. Şekil 10’da görüldüğü gibi Aynakıç ve Bodrum Guleti tipindeki yatların makine dairesi uzunluğunun teknenin gövde boyuna oranının birbirine oldukça yakın değerler aldığı sonucuna ulaşılmıştır. 
Tablo 2. Incelenen yelkenli yatlara ait makine dairesi oranları

\begin{tabular}{|c|c|c|c|c|c|}
\hline Tekne No & $\begin{array}{c}\text { Tam Boy } \\
(\mathrm{m})\end{array}$ & $\begin{array}{c}\text { Gövde Boyu } \\
(\mathrm{m})\end{array}$ & $\begin{array}{c}\text { Mak. Dairesi } \\
\text { Kıç (\%) }\end{array}$ & $\begin{array}{c}\text { Mak. Dairesi } \\
\text { Baş (\%) }\end{array}$ & $\begin{array}{c}\text { Mak. Dairesi } \\
\text { Toplam \% }\end{array}$ \\
\hline A.1 & 20.30 & 20.30 & 23.89 & 42.41 & 18.52 \\
\hline A.2 & 22.00 & 22.00 & 26.82 & 44.09 & 17.27 \\
\hline A.3 & 23.00 & 23.00 & 25.00 & 42.17 & 17.17 \\
\hline A.4 & 23.26 & 23.26 & 24.08 & 41.27 & 17.20 \\
\hline A.5 & 23.41 & 23.41 & 27.68 & 45.37 & 17.68 \\
\hline A.6 & 23.90 & 23.90 & 26.44 & 41.92 & 15.48 \\
\hline A.7 & 24.90 & 24.90 & 27.19 & 42.77 & 15.58 \\
\hline A.8 & 25.00 & 25.00 & 25.00 & 40.68 & 15.68 \\
\hline A.9 & 25.10 & 25.10 & 27.05 & 42.39 & 15.34 \\
\hline A.10 & 28.70 & 28.70 & 28.85 & 43.83 & 14.98 \\
\hline A.11 & 32.50 & 32.50 & 27.69 & 40.77 & 13.08 \\
\hline A.12 & 35.00 & 35.00 & 28.11 & 40.69 & 12.57 \\
\hline A.13 & 37.78 & 37.78 & 28.43 & 40.34 & 11.91 \\
\hline A.14 & 38.59 & 38.59 & 28.43 & 40.87 & 12.44 \\
\hline A.15 & 42.83 & 42.83 & 27.90 & 39.58 & 11.67 \\
\hline G.1 & 21.80 & 21.80 & 23.85 & 41.74 & 17.89 \\
\hline G.2 & 23.80 & 23.80 & 22.69 & 39.29 & 16.60 \\
\hline G.3 & 23.90 & 23.90 & 23.43 & 39.54 & 16.11 \\
\hline G.4 & 23.95 & 23.95 & 24.34 & 41.04 & 16.70 \\
\hline G.5 & 25.60 & 25.60 & 22.27 & 38.28 & 16.02 \\
\hline G.6 & 26.65 & 26.65 & 22.14 & 37.52 & 15.38 \\
\hline G.7 & 27.60 & 27.60 & 20.29 & 35.07 & 14.78 \\
\hline G.8 & 28.00 & 28.00 & 20.29 & 35.46 & 15.18 \\
\hline G.9 & 28.20 & 28.20 & 23.05 & 38.30 & 15.25 \\
\hline G.10 & 28.40 & 28.40 & 20.21 & 35.88 & 15.67 \\
\hline G.11 & 29.50 & 29.50 & 21.42 & 36.00 & 14.58 \\
\hline G.12 & 32.00 & 32.00 & 24.84 & 38.75 & 13.91 \\
\hline G.13 & 33.12 & 33.12 & 24.46 & 37.59 & 13.13 \\
\hline G.14 & 35.64 & 35.64 & 25.11 & 37.18 & 12.07 \\
\hline G.15 & 35.85 & 35.85 & 23.71 & 36.26 & 12.55 \\
\hline & & & & & \\
\hline
\end{tabular}

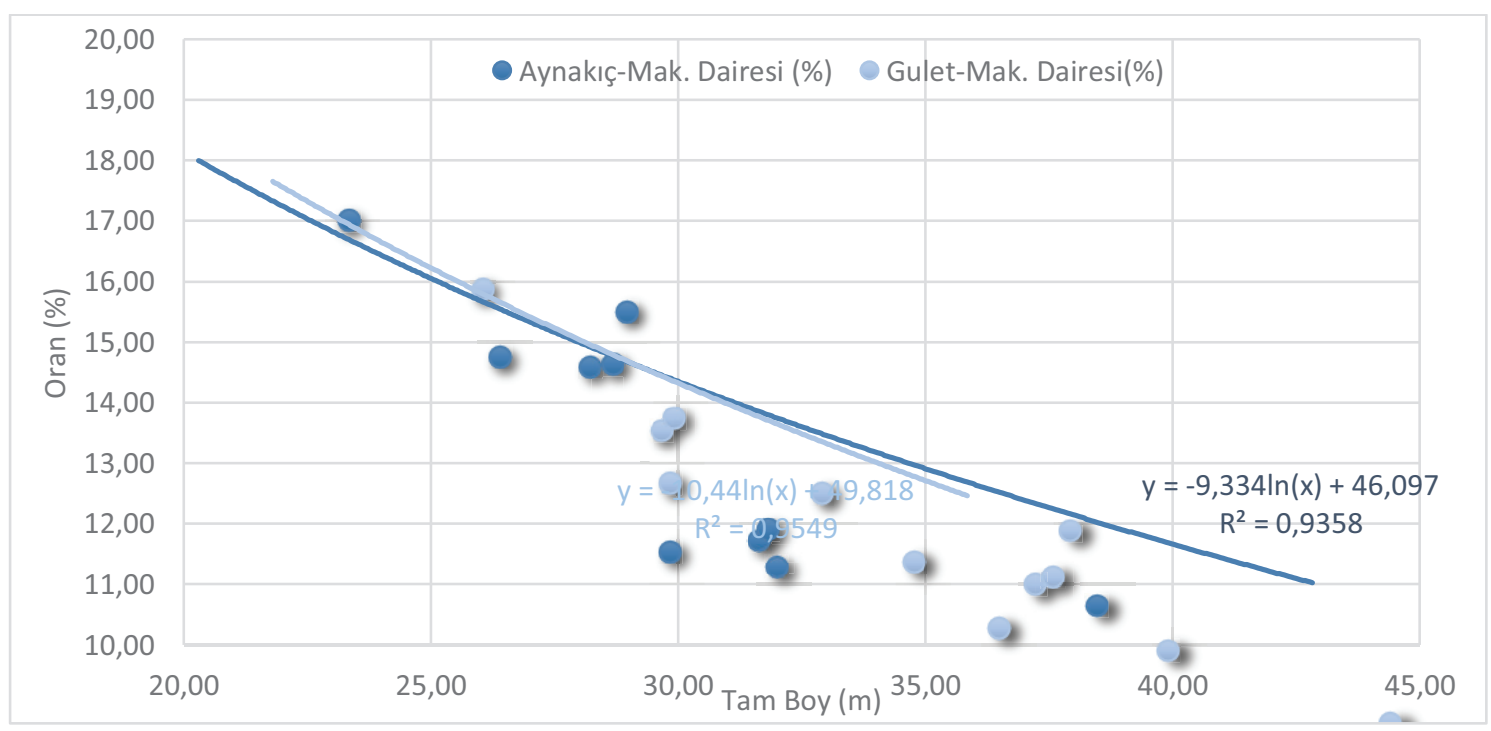

Şekil 10. İncelenen yelkenli yatların makine dairesi oran grafiği 


\subsection{Motoryatlar}

Incelenen 42 adet yelkenli yata ait değerler Tablo 3'te görülmektedir. Tablo 3'te yer alan değerlerin tekne tam boyuna bölünmesi ile elde edilmiş olan oranlar ise Tablo 4'te yer görülmektedir.

Tablo 3. Incelenen motoryatlara ait değerler

\begin{tabular}{|c|c|c|c|c|c|c|c|c|c|c|}
\hline $\begin{array}{c}\text { Tekne } \\
\text { No }\end{array}$ & $\begin{array}{c}\text { Tam Boy } \\
\text { (m) }\end{array}$ & $\begin{array}{c}\text { Gövde } \\
\text { Boyu (m) }\end{array}$ & $\begin{array}{l}\text { Su Hattı } \\
\text { Boyu } \\
\text { (m) }\end{array}$ & $\begin{array}{l}\text { Genişlik } \\
\text { (m) }\end{array}$ & $\begin{array}{l}\text { Motor } \\
\text { Adedi }\end{array}$ & $\begin{array}{c}\text { Makine } \\
\text { Dairesi } \\
\text { Boyu (m) }\end{array}$ & $\begin{array}{c}\text { Makine } \\
\text { Dairesi } \\
\text { Ortalama } \\
\text { Genişliği } \\
\text { (m) }\end{array}$ & $\begin{array}{c}\text { Mak. } \\
\text { Dairesi } \\
\text { Alanı }\left(\mathrm{m}^{2}\right)\end{array}$ & $\begin{array}{l}\text { Mak. } \\
\text { Dairesi Kıç } \\
\quad(\mathrm{m})\end{array}$ & $\begin{array}{c}\text { Mak. } \\
\text { Dairesi } \\
\text { Baş (m) }\end{array}$ \\
\hline T.1 & 15.00 & 14.50 & 13.50 & 4.80 & 2 & 3.00 & 4.40 & 13.20 & 3.70 & 6.70 \\
\hline T.2 & 18.33 & 17.50 & 16.80 & 6.21 & 2 & 3.40 & 5.15 & 17.51 & 3.00 & 6.40 \\
\hline T.3 & 18.95 & 17.40 & 16.47 & 5.41 & 2 & 3.40 & 5.41 & 18.39 & 4.10 & 7.50 \\
\hline T.4 & 19.00 & 18.00 & 16.40 & 5.50 & 2 & 3.50 & 3.50 & 12.25 & 3.20 & 6.70 \\
\hline T.5 & 20.00 & 19.50 & 18.00 & 6.20 & 2 & 3.60 & 6.10 & 21.96 & 4.80 & 8.40 \\
\hline T.6 & 20.70 & 19.50 & 18.10 & 5.50 & 2 & 3.70 & 5.20 & 19.24 & 5.20 & 8.90 \\
\hline T.7 & 23.90 & 23.00 & 22.43 & 6.90 & 2 & 4.10 & 6.80 & 27.88 & 7.60 & 11.70 \\
\hline T.8 & 25.00 & 23.20 & 22.06 & 6.60 & 2 & 4.00 & 6.30 & 25.20 & 4.70 & 8.70 \\
\hline T.9 & 25.00 & 23.50 & 21.50 & 6.40 & 2 & 4.10 & 6.00 & 24.60 & 6.20 & 10.30 \\
\hline T.10 & 29.50 & 28.20 & 27.60 & 6.60 & 2 & 4.70 & 6.00 & 28.20 & 6.00 & 10.70 \\
\hline F.1 & 21.00 & 20.50 & 18.05 & 5.23 & 2 & 4.10 & 5.15 & 21.115 & 3.00 & 7.10 \\
\hline F.2 & 21.20 & 21.00 & 17.55 & 5.26 & 2 & 4.30 & 5.25 & 22.575 & 3.50 & 7.80 \\
\hline F.3 & 20.75 & 19.50 & 17.90 & 5.45 & 2 & 4.10 & 5.30 & 21.73 & 2.50 & 6.60 \\
\hline F.4 & 22.00 & 21.20 & 18.70 & 5.40 & 2 & 4.30 & 5.00 & 21.5 & 2.90 & 7.20 \\
\hline F.5 & 24.70 & 23.20 & 18.50 & 5.74 & 2 & 4.40 & 5.74 & 25.256 & 2.80 & 7.20 \\
\hline F.6 & 24.75 & 22.80 & 20.50 & 5.76 & 2 & 4.20 & 5.70 & 23.94 & 3.00 & 7.20 \\
\hline F.7 & 25.20 & 23.70 & 21.50 & 6.06 & 2 & 4.60 & 6.00 & 27.6 & 4.00 & 8.60 \\
\hline F.8 & 25.60 & 25.00 & 19.60 & 5.86 & 2 & 4.70 & 5.70 & 26.79 & 3.20 & 7.90 \\
\hline F.9 & 26.20 & 24.00 & 22.50 & 6.30 & 2 & 4.50 & 6.30 & 28.35 & 4.10 & 8.60 \\
\hline F.10 & 26.20 & 24.80 & 22.40 & 6.30 & 2 & 4.50 & 6.30 & 28.35 & 3.50 & 8.00 \\
\hline F.11 & 28.00 & 26.70 & 21.04 & 6.23 & 2 & 4.70 & 6.20 & 29.14 & 3.20 & 7.90 \\
\hline F.12 & 28.00 & 27.00 & 25.00 & 7.00 & 2 & 4.85 & 6.90 & 33.47 & 4.80 & 9.65 \\
\hline F.13 & 28.50 & 26.90 & 23.10 & 6.50 & 2 & 4.80 & 6.20 & 29.76 & 4.00 & 8.80 \\
\hline F.14 & 30.00 & 30.00 & 24.35 & 6.90 & 2 & 5.10 & 6.80 & 34.68 & 4.20 & 9.30 \\
\hline F.15 & 29.90 & 27.50 & 26.00 & 6.80 & 2 & 4.90 & 6.75 & 33.08 & 4.80 & 9.70 \\
\hline F.16 & 31.10 & 30.80 & 29.80 & 7.10 & 2 & 5.20 & 7.10 & 36.92 & 5.20 & 10.40 \\
\hline F.17 & 32.00 & 31.00 & 31.00 & 7.60 & 2 & 5.00 & 7.60 & 38.00 & 5.10 & 10.10 \\
\hline F.18 & 33.50 & 33.40 & 28.30 & 7.30 & 2 & 5.40 & 7.25 & 39.15 & 5.80 & 11.20 \\
\hline F.19 & 34.36 & 34.20 & 32.25 & 7.70 & 2 & 5.50 & 7.50 & 41.25 & 5.90 & 11.40 \\
\hline F.20 & 36.50 & 36.50 & 34.00 & 7.50 & 2 & 5.65 & 7.50 & 42.38 & 6.00 & 11.65 \\
\hline F.21 & 36.80 & 36.50 & 34.00 & 7.80 & 2 & 6.00 & 7.80 & 46.80 & 7.10 & 13.10 \\
\hline F.22 & 37.00 & 36.80 & 35.20 & 8.60 & 2 & 5.90 & 8.60 & 50.74 & 6.90 & 12.80 \\
\hline F.23 & 40.00 & 38.50 & 34.55 & 8.30 & 2 & 6.10 & 8.20 & 50.02 & 8.00 & 14.10 \\
\hline F.24 & 40.08 & 43.95 & 38.80 & 8.50 & 2 & 6.65 & 8.45 & 56.19 & 7.00 & 13.65 \\
\hline F.25 & 42.00 & 42.00 & 41.20 & 9.00 & 2 & 6.50 & 9.00 & 58.50 & 8.70 & 15.20 \\
\hline F.26 & 42.50 & 42.50 & 41.80 & 9.00 & 2 & 6.50 & 9.00 & 58.50 & 8.85 & 15.35 \\
\hline F.27 & 43.00 & 43.00 & 42.50 & 9.00 & 2 & 6.50 & 9.00 & 58.50 & 9.10 & 15.60 \\
\hline F.28 & 43.00 & 43.00 & 40.50 & 8.10 & 2 & 6.20 & 8.10 & 50.22 & 8.00 & 14.20 \\
\hline F.29 & 44.06 & 43.85 & 41.00 & 9.05 & 2 & 6.30 & 9.00 & 56.70 & 8.80 & 15.10 \\
\hline F.30 & 48.00 & 48.00 & 45.00 & 9.50 & 2 & 6.60 & 9.50 & 62.70 & 9.00 & 15.60 \\
\hline F.31 & 49.90 & 49.90 & 49.60 & 10.20 & 2 & 7.10 & 10.10 & 71.71 & 10.20 & 17.30 \\
\hline F.32 & 49.90 & 49.90 & 48.20 & 9.20 & 2 & 7.00 & 9.10 & 63.70 & 9.50 & 16.50 \\
\hline
\end{tabular}


Tablo 4. Incelenen motoryatlara ait makine dairesi oranları

\begin{tabular}{|c|c|c|c|c|c|}
\hline Tekne No & $\begin{array}{c}\text { Tam Boy } \\
(\mathrm{m})\end{array}$ & $\begin{array}{c}\text { Gövde Boyu } \\
(\mathrm{m})\end{array}$ & $\begin{array}{l}\text { Mak. Dairesi } \\
\text { Kıç (\%) }\end{array}$ & $\begin{array}{c}\text { Mak. Dairesi } \\
\text { Baş (\%) }\end{array}$ & $\begin{array}{c}\text { Mak. Dairesi } \\
\text { Toplam \% }\end{array}$ \\
\hline T.1 & 15.00 & 14.50 & 25.52 & 46.21 & 20.69 \\
\hline T.2 & 18.33 & 17.50 & 17.14 & 36.57 & 19.43 \\
\hline T.3 & 18.95 & 17.40 & 23.56 & 43.10 & 19.54 \\
\hline T.4 & 19.00 & 18.00 & 17.78 & 37.22 & 19.44 \\
\hline T.5 & 20.00 & 19.50 & 24.62 & 43.08 & 18.46 \\
\hline T.6 & 20.70 & 19.50 & 26.67 & 45.64 & 18.97 \\
\hline $\mathrm{T} .7$ & 23.90 & 23.00 & 33.04 & 50.87 & 17.83 \\
\hline T.8 & 25.00 & 23.20 & 20.26 & 37.50 & 17.24 \\
\hline T.9 & 25.00 & 23.50 & 26.38 & 43.83 & 17.45 \\
\hline T.10 & 29.50 & 28.20 & 21.28 & 37.94 & 16.67 \\
\hline F.1 & 21.00 & 20.50 & 14.63 & 34.63 & 20.00 \\
\hline F.2 & 21.20 & 21.00 & 16.67 & 37.14 & 20.48 \\
\hline F. 3 & 20.75 & 19.50 & 12.82 & 33.85 & 21.03 \\
\hline F.4 & 22.00 & 21.20 & 13.68 & 33.96 & 20.28 \\
\hline F. 5 & 24.70 & 23.20 & 12.07 & 31.03 & 18.97 \\
\hline F. 6 & 24.75 & 22.80 & 13.16 & 31.58 & 18.42 \\
\hline F.7 & 25.20 & 23.70 & 16.88 & 36.29 & 19.41 \\
\hline F.8 & 25.60 & 25.00 & 12.80 & 31.60 & 18.80 \\
\hline F.9 & 26.20 & 24.00 & 17.08 & 35.83 & 18.75 \\
\hline F.10 & 26.20 & 24.80 & 14.11 & 32.26 & 18.15 \\
\hline F.11 & 28.00 & 26.70 & 11.99 & 29.59 & 17.60 \\
\hline F.12 & 28.00 & 27.00 & 17.78 & 35.74 & 17.96 \\
\hline F.13 & 28.50 & 26.90 & 14.87 & 32.71 & 17.84 \\
\hline F.14 & 30.00 & 30.00 & 14.00 & 31.00 & 17.00 \\
\hline F.15 & 29.90 & 27.50 & 17.45 & 35.27 & 17.82 \\
\hline F.16 & 31.10 & 30.80 & 16.88 & 33.77 & 16.88 \\
\hline F.17 & 32.00 & 31.00 & 16.45 & 32.58 & 16.13 \\
\hline F.18 & 33.50 & 33.40 & 17.37 & 33.53 & 16.17 \\
\hline F.19 & 34.36 & 34.20 & 17.25 & 33.33 & 16.08 \\
\hline F. 20 & 36.50 & 36.50 & 16.44 & 31.92 & 15.48 \\
\hline F.21 & 36.80 & 36.50 & 19.45 & 35.89 & 16.44 \\
\hline F.22 & 37.00 & 36.80 & 18.75 & 34.78 & 16.03 \\
\hline F.23 & 40.00 & 38.50 & 20.78 & 36.62 & 15.84 \\
\hline F. 24 & 40.08 & 43.95 & 15.93 & 31.06 & 15.13 \\
\hline F.25 & 42.00 & 42.00 & 20.71 & 36.19 & 15.48 \\
\hline F.26 & 42.50 & 42.50 & 20.82 & 36.12 & 15.29 \\
\hline F.27 & 43.00 & 43.00 & 21.16 & 36.28 & 15.12 \\
\hline F.28 & 43.00 & 43.00 & 18.60 & 33.02 & 14.42 \\
\hline F.29 & 44.06 & 43.85 & 20.07 & 34.44 & 14.37 \\
\hline F.30 & 48.00 & 48.00 & 18.75 & 32.50 & 13.75 \\
\hline F.31 & 49.90 & 49.90 & 20.44 & 34.67 & 14.23 \\
\hline F.32 & 49.90 & 49.90 & 19.04 & 33.07 & 14.03 \\
\hline
\end{tabular}

Incelenen motoryat tipi teknenin değerlerinden elde edilen oranlar, makine dairesinin baş konumlarının tekne boyuyla birlikte değişkenlik gösterdiğini ortaya koymaktadır. Motoryatların makine dairesi toplam boyunun teknenin tam boyuna oranı ile tekne tam boyu arasında tıpkı yelkenli yatlarda olduğu gibi 
logaritmik bir dağılım bulunduğu görülmüştür. Şekil 11, incelenen motoryatlardaki makine dairesi boyunun tekne tam boyuna oranının yüzde şeklinde dağılımını göstermektedir.

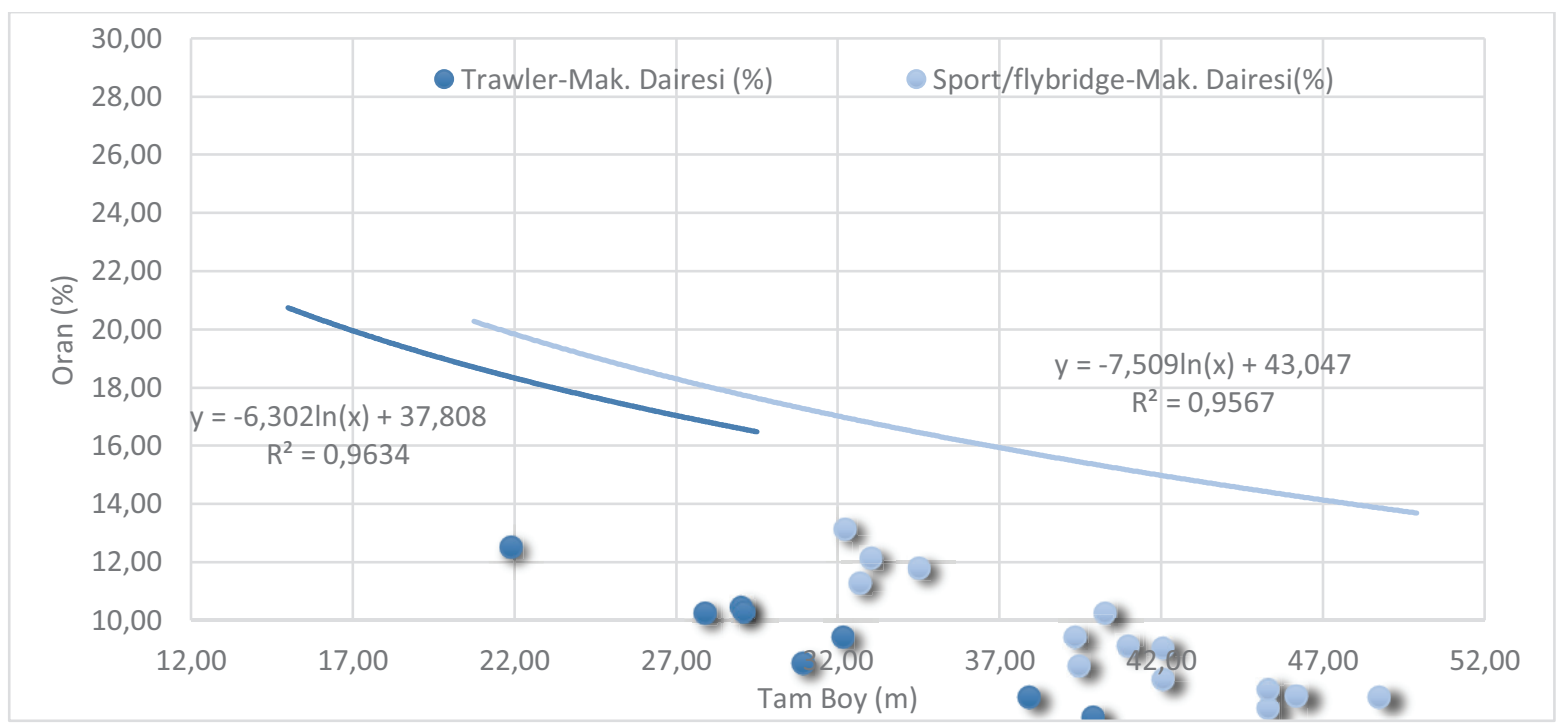

Şekil 11. Motoryatların makine dairesi boyunun tekne tam boyuna oranı

Elde edilen sonuçlar, trawler tipi motoryatların makine dairesinin uzunluğunun teknenin tam boyuna oranının, open, sport veya flybridge olarak tanımlanan motoryat tiplerininkine kıyasla daha düşük değerlerde olduğunu göstermektedir. Bununla birlikte, söz konusu orandaki farklılığın, yatların tam boyu arttıkça azaldığı da görülmektedir (Şekil 11).

\section{Değerlendirme ve Sonuç}

Yatların içinde bulunduğu deniz ortamının getirdiği statik ve dinamik kuvvetlerin etkisine bağlı olarak yat tasarım sürecinde hidrostatik, hidrodinamik, stabilite (denge), yapısal boyutlandırma gibi pek çok mühendislik hesabını gerçekleşmektedir. Yatların seyir ve güvenliği açısından büyük öneme sahip olan pek çok donanım ve sistemi içinde barındıran makine dairesi yat tasarım sürecinde belirleyici alanlardan bir tanesidir. Bu açıdan makine dairesinin alanının bölmelendirilmesi, yat tasarım sürecinde yer alan ilk adımlardan bir tanesi olarak görülmektedir. Söz konusu bölmenin yerinin ve tekne gövdesinde kapladığı uzunluğun yat tasarım sürecinde öngörülmesi, yatın teknik alanlar dışında kalan iç mekânların tasarım sürecinde olumlu etkiye sahip olacaktır. Yapılan araştırmada, yelkenli yatlar ve motoryatlar için makine dairesinin başlangıç ve bitiş noktaları ile makine dairesi toplam uzunluğunun tekne tam boyuna oranları elde edilmiştir. Araştırmanın sonucunda ayrıca aşağıdaki sonuçlar elde edilmiştir:

- Yelkenli yatlarda ve motoryatlarda makine dairesinin tekne gövdesinde kapladığı alanın, tekne boyuyla ters orantılı bir şekilde değişiklik gösterdiği görülmektedir.

- Yerleşim açısından arasında farklılıklar bulunan Bodrum Guletleri ile Aynakıç tipi yatların makine dairesi uzunluğunun teknenin tam boyuna oranında gözle görülür farklılıklar olmadığı görülmektedir. 
- İki farklı motoryat tipi olan trawler ve open/sport/flybridge tipi motoryatların makine dairesi uzunluğunun teknenin gövde boyuna oranlarında ciddi farklılklar olduğu görülmektedir. Trawler tipi yatlarda bu oranın daha düşük olması, bu yat tiplerinde hız ve performansın, diğer tipe kıyasla daha geri planda tutulması ile açıklanabilir.

Yat tasarım sürecinde yat ana tipinin ve yat alt tipinin belirlenmesinin ardından tekne tam boyunun elde edilmesi, incelenmiş olan yat tipleri için makine dairesine ait temel parametreleri sağlayacaktır. Öte yandan kullanıcı odaklı bir süreç olan yat tasarım sürecinde yattan beklenen hız performansı, ekonomik seyir hızı, motor adedi, yardımcı ekipmanların sayısı ve çeşitliliği gibi pek çok faktör, makine dairesi boyutlarının belirlenmesini etkilemektedir.

\section{Referanslar}

Arslan, B. (2010). Motoryatlarda Iç Mekan Tasarım Süreç ve Kriterleri. İstanbul Teknik Üniversitesi.

Aydın, M., \& Yılmaz Aydın, T. (2016). Türkiye'de İnşa Edilen Yatların İç Mekan Tasarımı Üzerine Bir Araştırma. Tasarım + Kuram, 12(21), 61-77. https://doi.org/10.23835/tasarimkuram.315688

Boat International Türkiye. (2021). Modern Çizgilerde Absolute Imzası. Boat International Türkiye. http://www.boatinternational.com.tr/modern-cizgilerde-absolute-imzasi/

Büyükkeçeci, E., \& Turan, B. I. (2018). Türkiye'de Tekne Tasarımında Tasarımcının Rolünün Araştırılması: Gulet ve Motor Yat Karşılaştırması. UTAK 2018- 3. Ulusal Tasarım Araştırmaları Konferansı: Tasarım ve Umut Bildiri Kitabı, 159-171.

Göksel, M. A. (2012). Deniz Aracı iç̧ Mekanında Biçimlenişs Süreci. Boatbuilder Türkiye. http://www.boatbuilderturkiye.com/yayin/292/deniz-araci-ic-mekaninda-bicimlenis-

sureci_9010.html\#.YSc2jo4zaUl

Kafalı, K. (1988). Gemilerin Dizaynı. İstanbul Teknik Üniversitesi.

Koçoğlu, H., \& Helvacıoğlu, Ş. (2016). Yat tasariminda ergonomi ve örnek bir motoryat tasarimina uygulanmasi. GIDB Dergi, 6, 23-40.

Köyağasıŏlu, Y. (2014). Denizin Kanatı Perileri Yelkenliler. Naviga Publishings.

Kükner, A. (2009). Türk Tipi Yelkenli Tekne Gulet. Gemi ve Deniz Teknolojisi, 181, 5-12.

Kükner, A., \& Kınacı, Ö. K. (2009). Bodrum Tipi Gulet Yat Serilerinin Matematiksel Modellemesi. Gemi ve Deniz Teknolojisi, 181, 13-17.

Kükner, A., Sarıöz, K., Güner, M., Bal, Ş., Akyıldız, H., Aydın, M., Turan, F., \& Özalper, F. (2009). 106 M086 Proje No'lu Tübitak Araştırma Projesi-Türk Tipi Guletlerin Incelenmesi ve Form Optimizasyonu.

Larsson, L., \& Eliasson, R. E. (2006). Yat Tasarımı Temel ilkeleri. Birsen Yayınevi.

Özen, S. (2017). Gemiler Sözlüğüu. Denizler Kitabevi. 
Özer, P., \& Tokol, T. (2021). Yatlarda ergonomi, işlev, biçim ve malzemenin donatılar üzerindeki etkisi. IDA: International Design and Art Journal, 3(1), 117-131.

Paker, S., \& Özgeçmez, Ö. (2014). Gulet Tatili ve Kadınların Gulet Tatili Satın Alma Tercihleri Üzerine Bir Araştırma. Dokuz Eylül Üniversitesi Denizcilik Fakültesi Dergisi, 6(2), 101-113.

Thomas, T. (2015). The owner's guide to superyacht naval architecture part 1 - learning your lines. Boat International. https://www.boatinternational.com/yachts/yacht-design/the-owner-s-guide-tosuperyacht-naval-architecture-part-1-learning-your-lines--723

Tokol, H. T. (2020). Yat İ̧̧ Mekan Tasarımında Tek Gövdeli ile Çift Gövdeli (Katamaran) Yatların Karşılaştırılması. International Journal of Interdisciplinary and Intercultural Art, 5(11), 59-84. https://doi.org/10.29228/ijiia.132

Turan, B. I. (2021a). Bodrum Guletleri ile Bodrum'daki Balıkçı Guletlerinin Formlarının Karşılaştırılması. Dokuz Eylül Üniversitesi Denizcilik Fakültesi Dergisi, Özel Sayı, 37-62. https://doi.org/10.18613/deudfd.751944

Turan, B. I. (2021b). Konfor ve Lüks Unsurlarının Bodrum Guletleri Üzerindeki Etkilerinin Araştırılması. Dokuz Eylül Üniversitesi Denizcilik Fakültesi Dergisi, 13(1), 37-55. https://doi.org/10.18613/deudfd.942940

Turan, B. I. (2021c). Yat Tasarım Sürecinde Tasarım-Mühendislik ilişkisi. IDA: International Design and Art Journal, 3(2), 210-223.

Turan, B. I., \& Akman, M. (2021). Modeling and Comparison of Bodrum Gulets' Hull Forms with Round and Transom Sterns. Journal of ETA Maritime Science, 9(2), 120-129. https://doi.org/10.4274/jems.2021.09327

Turan, B. I., \& Özcan, A. C. (2018). Akdeniz’e Özgü Bir Kültür ve Tasarım Etkinliği: Mavi Yolculuk ve Bodrum Guleti. 1. Uluslararası Akdeniz Sempozyumu, 180-200.

Türk Loydu. (2019). Türk Loydu Kuralları Cilt C, Kısım 9-Yatların Yapımı ve Klaslanmasına Ilişskin Kurallar. Türk Loydu. https://turkloydu.org/pdf-files/turk-loydu-kurallari/cilt-c/kisim-9-yatlarin-yapimi-veklaslanmasina-iliskin-kurallar-2019-TEMMUZ.pdf

Türkiye Cumhuriyeti Ulaştırma ve Altyapı Bakanlığı. (2015). Gemi ve Su Araçlarının Inşa, Tadilat ve BakımOnarım Yönetmeliği. Mevzuat Bilgi Sistemi. https://www.mevzuat.gov.tr/mevzuat?MevzuatNo=21217\&MevzuatTur=7\&MevzuatTertip=5 